ANNA WAWRZONEK

ORCID 0000-0003-0046-8212

Uniwersytet im. Adama Mickiewicza

$w$ Poznaniu

\title{
WYŁANIAJĄCY SIĘ RYNEK PRACY - REALIA I WYZWANIA RZECZYWISTOŚCI POSTPANDEMICZNEJ
}

\begin{abstract}
AвSTRACT. Wawrzonek Anna, Wyłaniajacy się rynek pracy - realia i wyzwania rzeczywistości postpandemicznej [The Emerging Labour Market - Realities and Challenges of Post-pandemic Reality]. Studia Edukacyjne nr 59, 2020, Poznań 2020, pp. 123-145. Adam Mickiewicz University Press. ISSN 1233-6688. DOI: $10.14746 /$ se.2020.59.7

Following my research interests, I would like to reflect on professional work and focus on its new realities and challenges that the various participants of the labour market will face. As the new shape and system of forces creating the changing labour market become a challenge not only for employers, business owners, but also for employees, contractors and finally for counsellors and educators, the initial part of the study will include a short analysis of the current situation on the labour market modified by the pandemic. Next, the author will present the consequences of these changes which will be analysed from the perspective of the employer and the employee. At this point, it is worth noting that a large part of the sources on the basis of which this study was created are the internet sources, current reports, and messages which during the pandemic seem to be the most up-to-date source material.
\end{abstract}

Key words: coronavirus, post-pandemic labour market, employability, competencies, resilience

\section{Wprowadzenie}

W przeciągu kilku wiosennych tygodni 2020 roku rynek pracy totalnie się zmienił. Dynamikę i kierunek tych zmian wyznaczał wirus, któremu bez przygotowania podporządkowane zostały wszystkie sfery życia społecznego. Bez względu na role pełnione w przestrzeni społecznej, bez względu na status społeczny, edukacyjny, zajmowane stanowisko COVID-19 wymusił przeorganizowanie dotychczasowego życia oraz utrwalonych nawyków. Pandemia koronawirusa stała się zjawiskiem, które zmieniło i nadal zmienia świat, w znaczący sposób wpłynęła na gospodarkę, edukację, służbę zdrowia, 
transport, politykę międzynarodową oraz sposób, w jaki postrzega się globalizację. Ponadto, oprócz zmian w obszarze gospodarki i biznesu pandemia wpłynęła również na indywidualne wybory, emocje, przekonania i potrzeby obywateli. Nieoczekiwanie zmienił się styl życia, a także jakość i intensywność kontaktów międzyludzkich. Pandemia stała się wydarzeniem epokowym, naznaczającym całe społeczeństwa, kształtującym ich tożsamość zbiorową oraz jednostkową. Szczególnie mocno wpłynęła na tożsamość młodych osób, wkraczających w dorosłość.

Przestrzenią, która szczególnie dotkliwie odczuwa skutki ingerencji wirusa, poza służbą zdrowia, jest gospodarka, a w niej rynek pracy. Zaistniała sytuacja spowodowała, iż jako społeczeństwo zmagamy się z wieloma niedogodnościami $w$ sferze zawodowej oraz ogromnym poczuciem niepewności również w tym obszarze. Nowa rzeczywistość wymaga skutecznych i przemyślanych działań, zarówno względem samych siebie, ale też rodzin, współpracowników, pracowników, czy pracodawców. Wymaga przeorganizowania dotychczasowej rutyny, utrwalonych nawyków, redefinicji priorytetów, czasami nawet przewartościowania dotychczasowego życia tak, aby jak najszybciej powrócić do normalności, która i tak nie będzie już tą sprzed pandemii. Przed społeczeństwami całego globu nowa postpandemiczna rzeczywistość rynkowa, edukacyjna, ale również relacyjna i osobista. A wraz z nią pytania o możliwości, kierunki rozwoju rzeczywistości „po pandemii” i jednocześnie brak odpowiedzi, kiedy wskazane i wyczekiwane "po" nastąpi.

$\mathrm{Z}$ racji swoich zainteresowań badawczych, przedmiotem niniejszego artykułu chciałabym uczynić refleksje na temat pracy zawodowej, ukierunkowane na jej nowe realia oraz wyzwania, z którymi mierzyć się będą różni aktorzy rynku pracy. W związku z faktem, iż nowy kształt i układ sił budujących zmieniający się rynek pracy staje się wyzwaniem nie tylko dla pracodawców, właścicieli firm, ale także dla pracowników, zleceniobiorców i wreszcie dla doradców oraz edukatorów, wstępną część opracowania zajmie krótka analiza aktualnej, zmodyfikowanej przez koronawirusa sytuacji na rynku pracy, a następnie analizie poddane zostaną konsekwencje tych zmian, które zostaną zaprezentowane z perspektywy pracodawcy oraz pracownika. W tym miejscu warto zaznaczyć, iż sporą część źródeł, na podstawie których powstało niniejsze opracowanie, stanowią źródła internetowe, bieżące raporty, komunikaty, które w czasie pandemii wydają się najbardziej aktualnym materiałem źródłowym.

\section{Wyłaniający się rynek pracy}

Analizując sytuację na rynku pracy, wyraźnie widać, iż pandemia przyspieszyła na nim prognozowane wcześniej zmiany, szczególnie te związane z technologią, a dodatkowo obudziła „demony przeszłości”, które wydawa- 
ły się już opanowane. Zjawiska wcześniej obecne na rynku pracy, odnośnie których jednak wypracowano strategie radzenia sobie z nimi, po raz kolejny wróciły do gry z jeszcze większą siłą. Mam tutaj na myśli głównie takie zjawiska, jak neet czy prekariat. Biorąc pod uwagę aktualną sytuację na rynku pracy, prawdopodobna wydaje się kolejna fala prekaryzacji, czyli ponowny wzrost niepewności na rynku pracy i zmniejszenie ochrony praw pracowniczych. Warto przypomnieć, iż ostatni wzrost prekariatu odnotowano po kryzysie w 2008 roku. Sytuacja niepewności na rynku pracy, spowodowana koronawirusem może doprowadzić do dalszego pogłębienia takich zjawisk, jak praca na umowach cywilno-prawnych czy wymuszane zakładanie jednoosobowej działalności gospodarczej. Doniesienia prasowe oraz medialne wskazują na fakt, iż w sposób najbardziej dotkliwy zmiany w obrębie pracy odczuły i będą odczuwały osoby, które wcześniej tworzyły kategorie tak zwanych grup ryzyka na rynku pracy, a wśród nich między innymi osoby młode. Jak wynika z badania Brytyjskiego Instytutu Badań Fiskalnych (IFS), skutki kryzysu wywołanego pandemią COVID-19 finansowo najbardziej odczują właśnie osoby do 25. roku życia, kobiety oraz pracownicy zatrudnieni w nisko płatnych zawodach. Jak zaznaczyli eksperci z IFS, znaczny odsetek osób z tych trzech grup jest zatrudniony w branżach, które musiały zamknąć swoje działalności na czas pandemii ${ }^{1}$. Globalny kryzys spowodowany pandemią COVID-19 będzie miał długoterminowy wpływ na kariery zawodowe młodych osób przed 25. rokiem życia, co skłoniło Międzynarodową Organizację Pracy (ILO - International Labour Organization) do określenia tej grupy demograficznej, jako „Pokolenie Lockdown”. W swoim najnowszym raporcie "Monitor" ILO argumentuje, że COVID-19 będzie miał „niszczący i nieproporcjonalny” wpływ na perspektywy zawodowe młodych osób. Pokolenie osób poniżej 25. roku życia jest w obecnej sytuacji narażone na potrójny szok na rynku pracy. Po pierwsze, osobom w tym wieku częściej grozi utrata pracy niż reszcie ludności aktywnej zawodowo. Po drugie, istnieje większe prawdopodobieństwo doznania przez nich zakłóceń w edukacji lub przerwania szkoleń zawodowych. Po trzecie, gorsza koniunktura oznacza, że młodzi napotkają na większe bariery przy wejściu na rynek pracy spowodowane mniejszym popytem ze strony pracodawców $^{2}$. Z kolei, według badania „Sytuacja polskich przedsiębiorstw i rynku pracy po lockdownie" wynika, iż 67\% firm zanotowało na przełomie kwiet-

${ }^{1}$ Portal Rynekpracy.pl, Na pandemii koronawirusa najwięcej straca finansowo młodzi ludzie i kobiety https://rynekpracy.pl/wiadomosci/na-pandemii-koronawirusa-finansowo-straca-najwiecej-mlodzi-ludzie-i-kobiety [dostęp: 30.06.2020].

2 P. Szewczyk, "Pokolenie Lockdown", czyli nowe problemy młodych osób na rynku pracy, https:// www2.deloitte.com/pl/pl/pages/press-releases/articles/Pokolenie-Lockdown-czyli-nowe-problemy-mlodych-osob-na-rynku-pracy.html?nc=1\&utm_campaign=IP_pokolenie_lockdown_C-RG-CON-06447_pl_2020_General_Email_pl\&utm_medium=email\&utm_ source=Eloqua [dostęp: 30.06.2020]. 
nia i maja spadki przychodów względem wyniku z marca, a co dziesiąta firma przyznała, że nie ma środków na przetrwanie ${ }^{3}$. Badania pokazują również, że najczęściej i w pierwszej kolejności pracę tracą te osoby, które znajdują się w najgorszej sytuacji, a wśród nich: osoby z niższym wykształceniem, gorzej wykwalifikowane, pracownicy dorywczy, sezonowi, kobiety z dziećmi, młodzi pracownicy bez doświadczenia, co w konsekwencji może doprowadzić do pogłębienia rozwarstwienia społecznego.

Obecna sytuacja wskazuje nie tylko na grupy pracowników mniej lub bardziej narażonych na utrudnienia w pracy, ale także na branże, które różnie sobie radzą $\mathrm{w}$ czasach pandemii. $Z$ problemami na rynku pracy mierzą i zmierzą się różne sektory, oprócz tych, które w pierwszej kolejności straciły najbardziej, czyli turystyki, hotelarstwa, branży kosmetyczno-fryzjerskiej i sportowej, kulturalnej. Warto zauważyć, iż kryzys dotyka także rolnictwo, które straciło pracowników, którzy w obliczu pandemii i po wprowadzeniu restrykcji dotyczących przekraczania granic zdecydowali się na powrót do kraju. Częściowo w obawie przed chorobą, ale też wielu z nich z powodu nagłej utraty pracy ${ }^{4}$. Warto zauważyć, iż wskazane kierunki zmian warunkują także zmiany w strukturze popytu na konkretne kompetencje pracowników, o czym autorka napisała w części artykułu dotyczącej pracowników.

Dodatkowo trzeba zaznaczyć, iż nowa sytuacja na rynku pracy przyczyniła się także do zmodyfikowanego postrzegania elastyczności zatrudnienia. Sytuacja pracy zdalnej, w nowych warunkach, poza miejscem zatrudnienia, w bardziej mobilnym czasie pracy stała się szansą dla ponownego podjęcia tematu nad zaletami pracy zdalnej, ale także nad koniecznością uelastycznienia tradycyjnego zatrudnienia oraz jeszcze większą potrzebą projektowania rozwiązań nie w kategoriach flexibility, ale flexicurity, która nie tylko rozluźni sztywne zasady tradycyjnego modelu pracy, ale przede wszystkim zadba o bezpieczeństwo socjalne pracownika.

Warto zauważyć, iż obok branż, które wyraźnie ucierpiały z powodu pandemii są również takie, którym nowe warunki sprzyjały. Wśród nich należy wskazać branżę spożywczą oraz e-commerce, gdzie gwałtownie wzrosło zapotrzebowanie na pracowników. Chodzi zarówno o osoby bezpośrednio zaangażowane $\mathrm{w}$ obsługę klienta, kompletowanie zamówień, ale i programistów, których potrzebują sklepy oraz platformy e-commerce. Dodatkowych pracowników potrzebują branże korzystające z boomu na zakupy w Internecie. Mowa przede wszystkim o pracownikach z branży dystrybucyjnej,

${ }^{3}$ M. Jarco, Co ósma firma zwolnita pracowników, a 18 proc. obniżyło płace, https://www.codziennypoznan.pl/artykul/2020-05-05/ badanie-co-osma-firma-zwolnila-pracownikow-a18-proc-obnizylo-place [dostęp: 31.05.2020].

${ }_{4}^{4}$ PulsHR.pl,https://www.pulshr.pl/praca-tymczasowa/koronawirus-a-rynek-pracy-nad ciaga-zmierzch-rynku-pracownika,72938.html [dostęp: 31.08.2020]. 
kurierach, kierowcach, spedytorach oraz obsłudze magazynów i centrów przeładunkowych ${ }^{5}$. Zwiększony popyt na konkretne zawody, kwalifikacje sprowokował także dyskusję na temat branż mniej i bardziej odpornych na COVID-19 oraz tak zwanych zawodów wirusoodpornych. Eksperci Fundacji Edukacyjnej „Perspektywy” rekomendują top 10 „wirusoodpornych” kierunków technicznych i ścisłych. Na liście znalazły się: kierunki informatyczne, cyberbezpieczeństwo, teleinformatyka, elektronika i telekomunikacja, inżynieria biomedyczna, inżynieria i analiza danych, matematyka i statystyka, modelowanie matematyczne i analiza danych, mikroelektronika $\mathrm{w}$ technice i medycynie oraz bioinformatyka i biologia systemów ${ }^{6}$. Bez wątpienia, są to zawody, które można określać mianem „przyszłościowych”, jednak warto pamiętać, iż zmiany sposobu świadczenia pracy w dobie koronawirusa pokazały, że branże które do tej pory w Polsce postrzegane były jako mniej innowacyjne, szybko zmuszone zostały do skoku cywilizacyjnego i tym samym stają się bardziej atrakcyjne. Autorka opracowania myśli tutaj głównie o branży edukacyjnej, w której zarówno pracownicy, jak i odbiorcy usług edukacyjnych bardzo szybko musieli przejść na system zdalny i w błyskawicznym tempie uzupełnić braki kompetencyjne we wskazanym zakresie. Oczywiście, warto zauważyć, iż rozwiązania typu webinaria, konferencje, czy konsultacje on-line miały wcześniej miejsce również $\mathrm{w}$ polskich warunkach, jednak skala oraz jakość tych działań sprzed i po, czy nawet $\mathrm{w}$ trakcie pandemii jest absolutnie nieporównywalna. Zmiany dokonujące się w edukacji uprawniają poniekąd do wskazania tego obszaru, ze względu na nowe technologie, które co prawda w sposób bardzo inwazyjny, jednak weszły do polskich szkół oraz innych instytucji edukacyjnych, jako tego który może najbardziej skorzystać na pandemii. W tym miejscu należy podkreślić, że szkoła zdalna nie zawsze, a może nawet $\mathrm{w}$ większości przypadków słabo się sprawdziła, ale na pewno otworzyła nowe możliwości i tym samym pokazuje, że zawód nauczyciela i praca w edukacji mogą być realizowane w nowoczesny sposób, a dodatkowo staje się profesją, która wbrew przewidywaniom nadal jest bardzo potrzebna.

Analizując zmiany na rynku pracy, spowodowane koronawirusem, warto także zaznaczyć, iż przyspieszony kurs digitalizacji biznesu paradoksalnie przyczynił się do zmian w obrębie pokoleń na rynku pracy. To co do tej pory przypisywano głównie młodszym pokoleniom, co było często postrze-

${ }^{5}$ K. Bagiński, Koronawirus a rynek pracy. Nie wszystkie branże stracity na epidemii, https:/ / www.money.pl/gospodarka/koronawirus-a-rynek-pracy-nie-wszystkie-branze-stracily-na -epidemii-sa-i-takie-ktore-szukaja-pracownikow-6494522090407553a.html. [dostęp: 15.06.2020].

${ }^{6}$ Newseria, Pandemia koronawirusa zmienia rynek pracy. W cenie będa zawody wykonywane zdalnie, https://www.codziennypoznan.pl/artykul/2020-05-13/pandemia-koronawirusa-zmienia -rynek-pracy-w-cenie-beda-zawody-wykonywane-zdalnie?fbclid=IwAR0AzirB8e5qZbIZZJpmg-B-1ghzg0gRZA3-ctjX813csLyVyy9BGER32mo [dostęp: 20.06.2020]. 
gane w kategoriach kompetencji wyróżniającej młodych, nagle stało się „być albo nie być" dla pracowników z wszystkich grup wiekowych. Czynnik najbardziej różnicujący pokolenia został bardzo szybko zneutralizowany. Dodatkowo zagrożenie spowodowane wirusem jest zagrożeniem, które dotyka każdego bez wyjątku na wiek, kompetencje, czy doświadczenie, co sprzyja zespoleniu różnych grup społecznych, w tym pracowniczych. Dla najmłodszych pokoleń funkcjonujących na rynku pracy jest to pierwsze doświadczenie tego rodzaju, pierwsze globalne wydarzenie, które dotyka bezpośrednio także ich życia, zmienia się zatem sposób funkcjonowania młodych, zarówno w przestrzeni osobistej jak i zawodowej. Od 2020 roku młodsi uczestnicy rynku pracy mają „swój kryzys”, który odciska głębokie piętno na ich życiu i tym samym skłania do zmiany życiowych postaw. Kryzys spowodowany pandemią ukazał słabe strony "systemu wartości” młodych; to co było ich pewnikiem, wyznacznikiem wolności i niezależności uległo, przynajmniej na chwilę, załamaniu. Życie zakorzenione w globalizacji, dającej nieograniczone możliwości przemieszczania się, nagle skończyło się albo zatrzymało i z perspektywy globalnej wszyscy zostali przymusowo skierowani do perspektywy lokalnej. Globalizacja nie została zatrzymana, ale tymczasowo bardziej doświadczamy jej w sferze wirtualnej niż realnej. Doniesienia z najświeższych raportów pokazują, iż rzeczywistość pandemiczna zmieniła podejście młodych do pracy. Z danych Raportu „Młodzi Polacy na rynku pracy w nowej normalności" wynika, że aż 81,5\% badanych młodych Polaków wybiera dzisiaj stabilność zatrudnienia zamiast pracę na własny rachunek. Doświadczanie pandemii przez młodych spowodowało, że pokolenie "Z" zaczęło cenić stabilność pracy i poczucie bezpieczeństwa, co do tej pory przypisywane było głównie starszym pokoleniom. „Zetki” planują też na dłużej związać się z jednym pracodawcą, co wcześniej definiowali raczej w kategoriach "frajerstwa” z ich strony ${ }^{7}$. Wyniki badań Deloitte Poland wskazują, iż w konsekwencji wirusa zmniejszyła się luka między różnicami pokoleniowymi w obszarze pracy i rozwoju zawodowego ${ }^{8}$. Cytowane wyniki badań pokazują, iż COVID-19 jest nie tylko wydarzeniem wyznaczającym kierunki rozwoju poszczególnych pokoleń, ale być może także czynnikiem spajającym pokolenia. Jest doświadczeniem, które może jednoczyć i w sposób, który do tej pory był mało realny motywować do współpracy międzypokoleniowej.

\footnotetext{
${ }^{7}$ Pwc Polska, Młodzi Polacy na rynku pracy w nowej normalności, czerwiec 2020.

${ }^{8}$ J. Guziak, TRENDY: Wielopokoleniowy zespót. Od milenialsów do pracowników z wieloletnim staże, na: https://www2.deloitte.com/pl/pl/pages/human-capital/articles/employeeexperience/wielopokoleniowy-zespol.html?utm_campaign=Newsletter_HR\%40Transformation_10_2020_C-RG-CON-06787_pl_2020_Consulting_Email_pl\&utm_medium=email\&utm_ source=Eloqua [dostęp: 20.08.2020].
} 
Wybiórcza analiza sytuacji nad zmodyfikowanym, żeby nie powiedzieć zmutowanym, wirusem rynku pracy, zaprezentowana w niniejszym opracowaniu pokazuje, iż konsekwencje COVID-u są ogromne i wielokierunkowe. W wyniku pandemii koronawirusa około 2,7 mld ludzi na świecie, czyli cztery na pięć osób pracujących zawodowo, zostało objętych jakąś formą ograniczenia lub kwarantanny9. Liderzy biznesowi oraz przywódcy polityczni musieli się zmierzyć z ogromnym wyzwaniem, reagować na bieżąco na sytuacje zrodzone przez kryzys, modyfikując swoje strategie zatrudnienia. W większości firm priorytetem stały się działania antykryzysowe obejmujące bezpieczeństwo, zdrowie oraz związane $\mathrm{z}$ tym przejście na pracę czy naukę zdalną. Zdaniem ekspertów cytowanego opracowania, jest to etap reagowania, podczas którego firma koncentruje się na bieżącej sytuacji oraz łagodzeniu jej skutków. Eksperci wskazują, iż następstwem przywołanego etapu będzie, a w przypadku niektórych organizacji już jest, kolejny krok: wychodzenie z kryzysu, w którym organizacja uczy się i zyskuje na sile i wreszcie trzeci ostatni, który z punktu widzenia przyszłości wydaje się najistotniejszy, czyli rozwój, postrzegany jako okres przygotowania oraz kształtowania „nowej normalności"10.

\section{Perspektywa pracodawcy}

Jak wspomniano wcześniej, jedną z perspektyw, która w niniejszym opracowaniu posłuży do analizy sytuacji na rynku pracy jest perspektywa pracodawcy. Dla niektórych z nich zmierzenie się z wirusem oznaczało walkę o ocalenie dorobku swojego życia, dla innych walkę o utrzymanie klientów oraz zabezpieczanie środków na wynagrodzenie dla pracowników. Dla innych słowo kryzys stało się pretekstem do podjęcia działań, czasami dość radykalnych i jednocześnie niekorzystnych dla pracobiorców. Pod przykrywką optymalizacji zatrudnienia niektórzy pracodawcy rozstali się z pracownikami, inni odebrali przysługujące im przywileje, w postaci rozbudowanych benefitów, bądź obniżyli wynagrodzenia. Działania te były wcześniej rozważane, jednak przedpandemiczna rzeczywistość rynku pracownika hamowała pracodawców przed podjęciem konkretnych działań. Koronawirus stał się czymś w rodzaju wyzwalacza bądź akceleratora konkretnych ruchów i decyzji, nie zawsze komfortowych dla pracowników. W tym miejscu trzeba zaznaczyć, iż niektórzy pracodawcy wykorzystali pandemię i w mało elegancki sposób potraktowali swoich pracowników. Tego typu zachowania

9 J. Schwartz i in., COVID-19: Strategia zatrudnienia na czas wychodzenia z kryzysu wywołanego wirusem COVID-19, Deloitte 2020, s. 2.

${ }^{10}$ Tamże, s. 3. 
w przyszłości zweryfikują z pewnością rankingi tak zwanych „firm przyjaznych pracownikowi".

Czas kwarantanny dla wielu aktorów rynku pracy był czasem „zdjęcia masek”, obnażającym iluzję sztucznie kreowanych wizerunków "przyjaznych pracodawców” bądź „lojalnych pracowników”. Kryzys nie tylko zdemaskował fałszywe intencje wielu pracodawców, ale też umocnił postawę tych, którzy są autentyczni w przekazie i sposobie funkcjonowania, tych którzy dbali i nadal dbają o personel oraz relacje oparte na szacunku do drugiego człowieka. Weryfikacja postaw pracodawców przekłada się na nową odsłonę kategorii pojęciowej społeczna odpowiedzialność biznesu, w miejsce której pojawi się szersza kategoria: biznes odpowiedzialny. Prowadzenie odpowiedzialnej firmy oznacza przekształcenie powiązań pomiędzy pracownikiem a pracodawcą oraz firmą a społeczeństwem w sposób stawiający człowieka $\mathrm{w}$ centrum uwagi ${ }^{11}$. Warto zauważyć, iż lockdown oraz związane z nim restrykcje nie tylko odkrył prawdziwe intencje pracodawców, ale także postawił przed nimi nowe wyzwania, związane z tym jak będzie wyglądał rynek pracy po pandemii, kiedy nie będzie powrotu do tego, co było wcześniej. Wszyscy aktorzy rynku pracy zderzą się z kompletnie nową rzeczywistością, która będzie kombinacją tego co pamiętamy z tym, czego aktualnie doświadczamy ${ }^{12}$. Zmienią się dotychczasowe modele współpracy, a w związku z tym, iż kluczowi pracownicy mogą być niedostępni, trzeba będzie budować bardziej sprawne, zaufane zespoły albo zespoły alternatywne, funkcjonujące $\mathrm{w}$ trybie pracy rotacyjnej. Przyszłość prawdopodobnie wymusi pracę w modelu blended-working, co oznacza, że wszyscy będą więcej pracować zdalnie niż przed epidemią, co być może przełoży się na to, iż jako społeczeństwo nauczymy się pracować efektywniej i szybciej. Warto jednak zauważyć, iż prognozowane zmiany wymagają przeorganizowania kultury organizacji większości firm i to wydaje się być największym wyzwaniem dla pracodawców, a z punktu widzenia działów personalnych najlepszym efektem ubocznym pandemii. Od kilku lat eksperci Digital University podkreślają, że kluczowym elementem $w$ transformacji cyfrowej jest zmiana kultury organizacji na bardziej zwinną, przyzwyczajoną do tej niepewności i gotową na dynamiczne dostosowanie się do nowych warunków ${ }^{13}$. Zmiany w obszarze kultury organizacyjnej prawdopodobnie zapoczątkują również zmodyfikowane podejście do elastycznych form zatrudnienia, zarówno wśród pracowników oraz pracodawców i skłoni pracodawców do poświęcenia większej uwagi tym formom pracy, a także ich modyfikacji w kierunku flexicurity, które będą

\footnotetext{
${ }^{11}$ Tamże, s. 6.

${ }_{12}$ J. Michalska, K. Patalan, Przyszłość pracy post-Covid, https://www.miesiecznik-benefit. pl/wywiad/news/przyszlosc-pracy-post-covid-1/ [dostęp: 12.06.2020].

${ }_{13}$ Tamże.
} 
jeszcze bardziej atrakcyjne dla pracowników. Elastyczne zatrudnienie oznacza dla pracownika więcej niezależności, ale też może dać mu poczucie bezpieczeństwa i wbrew pozorom stabilności, jeśli model elastycznego zatrudnienia zostanie wzbogacony działaniami z zakresu zabezpieczeń socjalnych. Większa dbałość o pracownika, również poprzez wdrażanie elastyczności zatrudnienia, połączonej z bezpieczeństwem socjalnym, pozwoli pracodawcom uniknąć sytuacji powrotu do sztywnego, tradycyjnego zatrudnienia oraz zabiegania o pracowników, którzy w trakcie kwarantanny przywykli już do nowoczesnych form pracy. W tym kontekście kolejnym wyzwaniem stojącym przed pracodawcami wydaje się zabieganie o dokładne uregulowanie kwestii prawnych w obszarze home-office, które nie tylko ułatwią funkcjonowanie pracodawcom, ale i pracownikom, a tym samym przyczynią się do poprawy dobrostanu psychicznego pracowników, co z dużym prawdopodobieństwem przełoży się na ich efektywność.

Analizując aktualną sytuację rynku pracy, warto zauważyć także, iż zmiany spowodowane wirusem COVID-19 mogą, niestety, przyczynić się do rozpoczęcia kolejnej fali zwolnień grupowych. Szacuje się, iż redukcje zatrudnienia nie ominą praktycznie żadnej branży i w optymistycznym scenariuszu resortu rodziny, pracy oraz polityki społecznej będą dotyczyły 1,4 miliona osób pracujących, w pesymistycznym wariancie bezrobocie w Polsce sięgnie $10 \%{ }^{14}$. Ograniczenia związane z lockdownem spowodowały, że firmy traciły zlecenia i wraz z malejącym popytem na produkty oraz usługi szukały oszczędności, redukując także zatrudnienie. Postępujący trend nie tyko postawi pracodawców przed wyzwaniem wprowadzenia profesjonalnych działań outplacementowych, ale po raz kolejny wskazuje na konieczność uelastycznienia rynku pracy, chociażby poprzez kontrakting, który w polskich warunkach nie jest rozwiązaniem powszechnie stosowanym, tymczasem na rynkach zachodnich stanowi trend wyraźnie rozwijający się. Zgodnie z badaniami CXC, do 2025 roku w światowych korporacjach pracownicy kontraktowi mają stanowić 30-50\% ogółu pracowników. W Polsce liczby te także będą wzrastać, gdyż w dobie pandemii i po niej próby utrzymania firmy przy konieczności zmniejszania kosztów jej prowadzenia będą oznaczały inwestycję w rozwiązania najbardziej ekonomiczne i opłacalne ${ }^{15}$.

Na tle przemian kompetencyjno-organizacyjnych wyraźnie kształtują się także trendy w polityce zarządzania zasobami ludzkimi. Prowadzenie firmy $\mathrm{w}$ dobie gospodarki 4.0, ale też zgodnie z założeniami odpowiedzialnego biz-

${ }^{14}$ Bergman Engineering, Rynek pracy w czasie koronawirusa - zamiast na umowę będą zatrudniać na kontrakt, https://ksiegowosc.infor.pl/zus-kadry/zatrudnianie-i-zwalnianie/4573326,Rynek -pracy-w-czasie-koronawirusa-zamiast-na-umowe-beda-zatrudniac-na-kontrakt.html [dostęp: 31.05.2020].

15 Tamże. 
nesu, będzie wymagało od pracodawcy zmiany podejścia na takie, w którym to pracownik stanie w centrum strategii biznesowej. Jak wskazują wyniki Raportu Human Capital Trends 201916, w pracowniku należy widzieć przede wszystkim człowieka, co oznacza, że trzeba wzmacniać jego podmiotowość w organizacji, przestać traktować go instrumentalnie w kategoriach generatora zysków i nośnika konkretnych, użytecznych kompetencji, ale stworzyć odpowiednie warunki do rozwoju pracowników, uwzględniając przy tym ich indywidualne potrzeby. Zmiany wyczekiwane jeszcze przed pandemią oraz przyszłościowe prognozy rynku pracy wydają się być zapowiedzią nowej jakości pracy, ale stawiają też wiele wyzwań przed instytucjami edukacyjnymi oraz biznesowymi, jak i samymi pracodawcami. COVID-19 fundamentalnie zmienił i zmieniać będzie kulturę organizacyjną, ustali, w jaki sposób dystrybuować pracę, rozszerzać i uruchamiać przestrzeń pracy, jak angażować ludzi. W dłuższej perspektywie czasowej prognozowane zmiany będą sprzyjały rozwojowi komunikacji w miejscu pracy, kreowaniu bardziej elastycznego środowiska pracy, skoncentrowanego również na zdrowiu i dobrostanie pracownika, a nie wyłącznie na celach organizacji. COVID można potraktować jako zapłon do wdrażania strategii skoncentrowanej na człowieku, na jego potrzebach, które można połączyć z potrzebami i celami firmy. Ludzie chca, żeby ich praca niosła ze sobą znaczenie, nie tylko dla firmy, czy klientów, ale również dla nich samych, dla ich kariery zawodowej. Nowe podejście do pracownika, do organizacji pracy jest potwierdzeniem troski firmy o dobro swoich pracowników. Oznacza ono takie ukierunkowanie na cel, który $\mathrm{w}$ harmonijny sposób zespoli indywidualne potrzeby pracownicze $\mathrm{z}$ wartościami płynącymi z dobra pracowników, ich wkładu w działalność biznesu i pracy ${ }^{17}$. Ważne jest, aby pracownicy mieli poczucie więzi z misją organizacji, gdyż to ich motywuje do zaangażowania i daje poczucie przynależności do zespołu pracowniczego, co z kolei przekłada się na poczucie bezpieczeństwa oraz umocnienie tożsamości zawodowej pracowników.

Kolejnym i jednocześnie ostatnim, wskazanym w tym opracowaniu, wyzwaniem, stojącym przed pracodawcami w obliczu pandemii, jest przeformułowanie sposobu myślenia o procesie globalizacji, który $\mathrm{w}$ trakcie pandemii został wyraźnie osłabiony. Zmiana myślenia o procesach globalizacyjnych jest związana między innymi z ograniczeniem handlu międzynarodowego, zamykaniem granic oraz częściowym zawieszeniem połączeń transportowych $\mathrm{w}$ trakcie lockdownu. Choć trudności te prawdopodobnie będą miały charakter przejściowy i wracają do normy, otwartym zagadnieniem pozostaje nowy charakter globalizacji po opanowaniu pandemii.

\footnotetext{
${ }^{16}$ Human Capital Trends 2019, Deloitte 2019.

${ }^{17}$ J. Schwartz i in., COVID-19: Strategia zatrudnienia na czas wychodzenia z kryzysu, s. 10.
} 
Osłabienie globalizacji automatycznie wzmacnia trendy lokalnościowe, zgodnie z założeniem, że to co bliżej jest bardziej wartościowe oraz autentyczne i przede wszystkim dostępne. Tym samym, otwiera się przestrzeń dla wzmacniania rozwiązań, które realizowane są na poziomie lokalnym. Autorka ma tutaj na myśli rozwiązania, angażujące w sprawy rynku pracy organizacje pozarządowe, lokalnych przedsiębiorców, instytucje edukacyjne oraz podejmowanie inicjatyw rozwojowych poprzez wykorzystywanie mechanizmów partnerstwa lokalnego.

Biorąc pod uwage szereg działań, wyzwań stojących przed pracodawcami, warto raz jeszcze podkreślić, iż są to wyzwania natury organizacyjnej, prawnej, ale także „przekonaniowej” związanej z wyznaczaniem nowych kierunków rozwoju przedsiębiorstw, uwzględniających wzmocnioną rolę pracownika i jego podmiotowość w strategiach rozwojowych firm.

\section{Perspektywa pracownika}

Wybuch pandemii zmienił diametralnie sytuację na rynku pracy, postawił szereg wyzwań przed pracodawcami, ale spowodował też szereg trudności, z którymi mierzą się pracownicy. Aktualne dane z rynku pracy pokazują, iż to czego pracownicy obawiają się najbardziej, to redukcja zatrudnienia (25\%), zmniejszenie wynagrodzenia (41\%) oraz likwidacja firmy $(16 \%)^{18}$. Obawy i lęki pracownicze spowodowane pandemią skłaniają do rozpatrywania trendów, wyzwań rynku pracy również z ich perspektywy, generując tym samym potrzebę podejmowania działań, które pozwolą pracownikom utrzymać się na rynku pracy. Pandemia stała się czynnikiem, który skłania pracowników do działań w kierunku przebranżowienia się, w celu wzmocnienia swojej pozycji na rynku, bądź zmiany pracy i szukania jej w bardziej stabilnych sektorach. Według danych pracuj.pl, aktualnie zmianę zawodu rozważa aż $64 \%$ polskich pracowników. Z raportu wynika również, iż oprócz wszechobecnego nastroju niepewności, zdecydowanie widać „gotowość Polaków na zmianę ścieżki zawodowej i przyjęcie nowych wyzwań w karierze"19. Uzyskane dane pokazują, iż sytuacja związana z zatrudnieniem $\mathrm{w}$ takim samym stopniu dotyka pracodawców, jak i pracobiorców. Zatem, przyjmując perspektywę pracownika, jako istotnego zasobu rynku pracy, warto wskazać najistotniejsze kompetencje pracownicze, których rozwijanie i posiadanie wydaje się niezbędne do efektywnego funkcjo-

${ }^{18}$ Interia.pl, informacja prasowa, Pandemia zmusza wielu pracowników do zmiany zawodu, https:/ / biznes.interia.pl/praca/news-pandemia-zmusza-wielu-pracownikow-do-zmiany-zawodu,nId,4546953?parametr=zobacz_takze [dostęp: 17.06.2020].

19 Tamże. 
nowania na „nowym” rynku pracy. Spora ich część, to kompetencje, cechy bądź dyspozycje identyfikowane i pożądane na rynku pracy jeszcze przed pandemią, jednak zmieniły się oczekiwania, co do stopnia ich zaawansowania, a czasami również sposobu ich wykorzystywania. Warto zauważyć, iż kryzys związany z lockdownem wygenerował zapotrzebowanie na nową elastyczność, umiejętności zarządzania sobą oraz zadaniami, wreszcie umiejętności związane z wykorzystywaniem narzędzi cyfrowych. Wszystkie je możemy określić mianem organizacyjnych, odnoszących się do zorganizowania sobie pracy zdalnej, przeorganizowania funkcjonowania w otoczeniu domowym w taki sposób, aby wykonywać pracę za pomocą dostępnych, ale też dedykowanych konkretnej pracy narzędzi, optymalizować czas spędzony przed ekranem i nie zaniedbać życia osobistego. Dla większości pracowników, poza branżami IT, praca z domu jest nowym doświadczeniem, często bardzo trudnym, $\mathrm{w}$ dodatku pozbawionym wyboru, ale koniecznością wynikającą z zaistniałej sytuacji. Pomimo tego, iż kompetencje z zakresu zarządzania sobą oraz pracą są kompetencjami, które od lat zajmują najwyższe miejsca na listach tych pożądanych, większość pracujących osób dopiero teraz miało okazję zmierzyć się z nimi w praktyce. Zaistniała sytuacja otwiera przestrzeń do dyskusji nad rozumieniem czy nawet bardziej praktykowaniem work-life balance. Trendy rynku pracy sprzed pandemii, ale także rozwój nowoczesnych technologii, mediów społecznościowych i wreszcie aktualna sytuacja spowodowana wirusem wyraźnie pokazują, iż myślenie o równowadze między życiem zawodowym a życiem prywatnym jako zupełnym rozdzieleniu tych światów jest jednak mało realne, a wizja oddzielania tych przestrzeni wyczerpuje się, ponieważ stwarza wrażenie konkurencji pomiędzy zróżnicowanymi aktywnościami istotnymi dla poszczególnych jednostek. Interesującą odpowiedzią na wyzwania współczesnego rynku pracy, szczególnie tego zmodyfikowanego przez okres izolacji społecznej, wydaje się koncepcja work-life integration albo work-life blending, która zakłada, iż świat zawodowy i prywatny muszą ze sobą współistnieć, a uczestnicy tych światów powinni się między nimi płynnie przełączać. Zaproponowane podejście jest coraz częściej promowane przez współczesnych menadżerów oraz portale HR-owe i już wcześniej było chętnie praktykowane przez przedstawicieli najmłodszych pokoleńn ${ }^{20}$. Nowe podejście do życiowego balansu wskazuje na konieczność rozwinięcia kompetencji

${ }^{20}$ Por. B. Harrington, J.J. Ladge, Work-life integration: Present Dynamics and Future Directions for Organizations, Organizational Dynamics, Vol. 38, No.2, pp. 148-157, 2009; https://gethppy. com/workplace-happiness/work-life-balance-to-work-life-blending, https://www.inc.com/ principal/forget-work-life-balance-work-life-blending-is-the-key-to-happiness.html, https:// www.rp.pl/Praca/190229534-Work-life-balance-i-work-life-integration---czym-charakteryzuja-sie-te-podejscia.html; https://www.hbrp.pl/b/work-life-integration/P9MVaF9Da [dostęp: 08.07.2020]. 
samoorganizacyjnych, umożliwiających płynne przenikanie między światem pracy i życiem osobistym, umiejętności zorganizowania miejsca oraz czasu pracy w przestrzeni, która do tej pory była zarezerwowana wyłącznie do celów związanych z życiem osobistym, rodzinnym. Wskazane umiejętności związane są także z zaadaptowaniem się do warunków wynikających z elastycznych form zatrudnienia. Oprócz kompetencji samoorganizacyjnych, które będą jeszcze bardziej pożądane w sytuacji pracy zdalnej czy hybrydowej, nadal w cenie są szeroko rozumiane kompetencje cyfrowe, czy tak zwane kompetencje przyszłości, szeroko komentowane w przestrzeni społecznej oraz analizowane w wielu opracowaniach ${ }^{21}$. Nowy paradygmat zatrudnienia przedkłada również umiejętności społeczne i osobiste nad konkretną wiedzę specjalistyczną.

Śledząc tendencje rynku pracy, nowe warunki świadczenia pracy warto zauważyć, iż w cenie nadal są unikalne cechy ludzkie i kompetencje, wśród których wymienia się inteligencję społeczną, myślenie systemowe, wyobraźnię, empatię, innowacyjność, kreatywność oraz improwizację i nie znaleziono na nie do tej pory algorytmu, co oznacza, iż są niezastępowalne przez maszyny ${ }^{22}$.

Uwagę trzeba także zwrócić na fakt, iż koronawirusowe realia sprzyjają wzrostowi znaczenia zatrudnialności. Na gruncie polskim przywołane pojęcie zyskało popularność w XXI wieku, co miało związek głównie z przystąpieniem Polski do Unii Europejskiej. Określenie employability zarówno w polskiej, jak i zagranicznej literaturze definiowane jest w różnoraki sposób. Przywołane pojęcie analizuje się zarówno na poziomie makroekonomicznym, odnoszącym się globalnie do rynku pracy oraz mikroekonomicznym, jednostkowym, odnoszącym się do poszczególnych osób. W kontekście niniejszego opracowania bardziej użyteczna wydaje się perspektywa indywidualna, która w obliczu zmian relacji pracownik-pracodawca, na nowo ułożonej przez COVID-19, wydaje się być dosyć istotna. Według M. Kabaja, pojęcie zatrudnialności obejmuje cztery elementy: oznacza skuteczność jednostki na rynku pracy, umiejętność dostosowania się do struktury popytu, poszukiwanych kwalifikacji i umiejętności, indywidualne promowanie zdolności do zatrudnienia. Zatrudnialność oznacza główną odpowiedzialność jednostki lub grup zawodowych za swoją przyszłość na rynku pracy; stwarzanie szans aktywizacji jednostki przez programy na rynku pracy oraz interaktywną zdolność do zatrudnienia, co oznacza,

${ }^{21}$ N. Hatalska, Pracownik przyszłości, Gdańsk, 2019; S.M. Kwiatkowski (red.), Kompetencje przyszłości, Warszawa 2018; R. Włoch, K. Śledziewska, Kompetencje przyszłości. Jak je kształtować w elastycznym ekosystemie edukacyjnym?, Warszawa 2019.

22 A. Goncalves, Coronavirus: Fighting Unemployment by Learning Tech Skills, https:// youmatter.world/en/coronavirus-unemployment-tech-skills/. [dostęp: 18.07.2020]. 
że w proces zatrudnienia powinni być włączeni wszyscy "aktorzy” rynku pracy, a nie tylko indywidualne jednostki" ${ }^{23}$. W aspekcie indywidualnym zatrudnialność oznacza zatem zdolność do pozyskania pracy, ale także jej utrzymania, zarówno zatrudniając się u kogoś, jak i prowadząc własną działalność oraz możliwość rozwoju kariery zawodowej dzięki elastyczności oraz nabytym wcześniej umiejętnościom, które pozwalają na wykorzystanie i optymalizowanie rozwijanego wcześniej kapitału kompetencyjno -kwalifikacyjnego. Korzystając z analiz U. Jeruszki, należy podkreślić, że biorąc pod uwagę perspektywę mikroekonomiczną, wskazuje się na trzy istotne cechy zatrudnialności, a wśród nich: potrzebę uzyskania od początku jakościowo znaczącego zatrudnienia, utrzymania go, a także umiejętności poruszania się po nim, zmiany zatrudnienia, zarówno na wewnętrznym, jak i zewnętrznym rynku pracy ${ }^{24}$. Odwołując się do przywołanych definicji, można powiedzieć, iż zatrudnialność stanowi ważny wskaźnik zaradności na rynku pracy, szczególnie w sytuacji niesprzyjających pracownikowi warunków, a za takie można uznać te, które powstały w wyniku pandemii. Ewidentny zwrot w kierunku rynku pracodawcy, od dosyć mocno ugruntowanego rynku pracownika przed pandemią, wyzwala większe zapotrzebowanie na zatrudnialność, nie tylko w dotychczasowej formie, ale też nieco zmodyfikowanej czy rozbudowanej. Zmiany na rynku pracy stawiają przed pracownikiem wymóg rozwijania tych cech i umiejętności, które zwiększą ich zatrudnialność i atrakcyjność na rynku pracy. Z tej perspektywy szczególnie ważne w obecnej sytuacji, oprócz wskazanych kompetencji z zakresu samozarządzania i organizacji, wydają się proaktywność i rezyliencja, pojęcia które być może powinny stanowić fundament zatrudnialności.

Proaktywność to postawa, w której jednostka jest odpowiedzialna za swoje życie poprzez świadome dokonywanie wyborów, ustalanie oraz osiąganie celów. Osoby proaktywne działają w obszarze swojego wpływu, mają świadomość swoich zasobów oraz możliwości i korzystają z nich. Według A. Bańki, osoby zachowujące się w ten sposób cechują się siedmioma charakterystykami profilu osoby proaktywnej, takimi jak: poszukiwanie możliwości zmiany, ustanawiania efektywnych i zorientowanych na zmianę celów, antycypowanie problemów oraz podejmowanie środków zaradczych, tendencja do robienia różnych rzeczy oraz robienia ich $\mathrm{w}$ inny sposób niż osoby reaktywne, podejmowanie różnych akcji oraz podejmowanie nowych wyzwań, bycie upartym (wytrwałym) oraz konsekwentne realizowanie swoich planów, osiąganie celów oraz legitymizacja konkretnymi osiągnięciami. Wskazane charakterystyki manifestują się zarówno poprzez osobowość jednostek

${ }^{23}$ M. Kabaj, Wptyw systemów kształcenia zawodowego na zatrudnienie i bezrobocie młodzieży, Warszawa 2012, s. 72.

${ }^{24}$ U. Jeruszka, Zatrudnialność w perspektywie pedagogiki pracy, Warszawa 2019, s. 67. 
oraz okoliczności sytuacyjne, w których jednostka funkcjonuje ${ }^{25}$. W literaturze przedmiotu częściej podejmuje się zagadnienia proaktywności z perspektywy jednostkowej i wydaje się, iż rozpatrywanie jej w tych kategoriach wpisuje się $\mathrm{w}$ koncepcję zatrudnialności, jednak sytuacja pandemii i jej konsekwencje dla rynku pracy bardzo mocno podkreślają także znaczenie okoliczności sytuacyjnych, kontekstu w którym jednostka funkcjonuje, co z kolei pokazuje, iż paradoksalnie niesprzyjające warunki spowodowane utrudnieniami wirusowymi mogłyby stać się kontekstem do wyzwolenia postaw proaktywnych u wybranych jednostek. Oczywiście, zdecydowanie łatwiej będzie osobom, które wykazują skłonności osobowościowe do bycia proaktywnym, gdyż pracownik proaktywny będzie wyznaczał sobie cele zawodowe i dokładał wszelkich starań, by je osiągać, będzie czuł się odpowiedzialny za swoją przyszłość i potrafił wyciągać wnioski z porażek. Dla odmiany, pracownik przyjmujący postawę reaktywną nie czuje się odpowiedzialny za swój los, winą za niepowodzenia obarcza otoczenie, a wszelkiego rodzaju przeciwności demotywują go do dalszych prób.

Aktualna sytuacja rynkowa prawdopodobnie wzmocni zachowania proaktywne u osób, których działania karierowe do tej pory były ukierunkowane na realizację celów zawodowych oraz dążenie do wewnętrznej satysfakcji, skoncentrowane na rozwijaniu umiejętności samodzielnego rozwiązywania problemów oraz samorealizacji, ponieważ osoba przyjmująca postawę proaktywną postrzega poszczególne zadania zawodowe $\mathrm{w}$ kategorii szans i wyzwań, a nie komplikacji i niepowodzeń. Dzięki temu może konstruktywnie rozwiązywać sytuacje problemowe, nabywając i doskonaląc różne umiejętności, a także osiągając sukcesy ${ }^{26}$. Prezentowana postawa zdecydowanie przełoży się na wzrost zatrudnialności pracownika.

Niestety, powrót do rynku pracodawcy, ograniczone możliwości znalezienia zatrudnienia, większe ryzyko utraty pracy procentują także postawą reaktywną u sporej części potencjalnych pracowników, szczególnie tych, którzy należą do kategorii określanej mianem NEET. Niesprzyjające okoliczności mogą stać się dla osób należących do tej grupy przesłanką usprawiedliwiającą i wzmacniającą ich bierność.

Z „Raportu o inflacji” Narodowego Banku Polskiego ${ }^{27}$ wynika, iż wybuch pandemii COVID-19 przyczynił się również do spadku potencjalnego zasobu siły roboczej, co wynika przede wszystkim ze zwiększonego niedopasowania

25 A. Bańka, Proaktywność a tryby samoregulacji. Podstawy teoretyczne, konstrukcja $i$ analiza czynnikowa Skali Zachowań Proaktywnych w karierze, Poznań - Warszawa 2016, s. 9-11.

${ }^{26}$ Portal pracuj.pl, https://porady.pracuj.pl/kariera-i-rozwoj/postawa-proaktywna-i-reaktywna-w-zyciu-zawodowym/ [dostęp: 15.07.2020].

27 D. Szymański, NBP kreśli czarny scenariusz dla rynku pracy w Polsce. "Coraz gorsze dopasowanie", https://businessinsider.com.pl/finanse/makroekonomia/rynek-pracy-w-polsce-z-raportu-o-inflacji-narodowego-banku-polskiego/mk5dhhe) [dostęp: 18.07.2020]. 
na rynku pracy. Część zwalnianych pracowników w dotkniętych kryzysem sektorach nie znajdzie innej pracy, ze względu na brak wymaganych kwalifikacji i umiejętności oraz czas potrzebny do ich nabycia. Zarysowana sytuacja prawdopodobnie wywoła dwojakie skutki: z jednej strony zadziała motywująco na pracowników, którzy muszą zawalczyć o swoją pozycję na rynku pracy, co można łączyć z proaktywną postawą wobec swojej kariery zawodowej, a z drugiej może utrwalić zwątpienie bądź załamanie. W tym kontekście niezwykle ważne wydaje się rozwijanie takich kompetencji, które nie tylko będą sprzyjały rozwojowi proaktywności, ale również takich, które przygotują osoby aktywne zawodowo, bądź które dopiero podejmą pracę, na trudności, z którymi muszą się mierzyć. Dlatego, warto poświęcić trochę więcej uwagi kategorii pojęciowej, jaką jest rezyliencja. Decyduje ona o tym, jak przechodzimy trudne i zmienne sytuacje, również te związane z aktywnością zawodową. O rezyliencji stanowią zasoby mentalne, takie jak determinacja, poczucie własnej wartości i życzliwość, czyli umiejętności radzenia sobie z przeciwnościami i stawiania czoła wyzwaniom na drodze do wykorzystania pojawiających się możliwości ${ }^{28}$. Według autorów cytowanego opracowania, prawdziwa rezyliencja sprzyja dobrostanowi, czyli podstawowemu poczuciu szczęścia, miłości i spokoju ${ }^{29}$. Przenosząc tę definicję na obszar zawodowy, rezyliencja powinna oznaczać umiejętność „wychodzenia na prostą" po trudnych doświadczeniach zawodowych. Składają się na to między innymi jednostkowy sposób radzenia sobie ze stresem, elastyczność w przyjmowaniu kolejnych zmian, nastawienie do nowych, zaskakujących sytuacji, umiejętność radzenia sobie z nieprzewidywalnością i brakiem stabilności ${ }^{30}$, co w obliczu pandemii wydaje się niezwykle ważne. Taki sposób definiowania rezyliencji wskazuje, iż jest ona swego rodzaju narzędziem pozwalającym na radzenie sobie $\mathrm{z}$ trudnymi sytuacjami oraz adaptację do nich i wreszcie gwarantuje sprawne funkcjonowanie $w$ zmienionym otoczeniu. Rezyliencja jest właściwością ułatwiającą minimalizowanie stresu i eliminację pojawiających się przeciwności, zdolnością do działania pomimo doświadczania porażek, a także umiejętnością radzenia sobie z silnymi wahaniami nastroju, zdolnością do poprawy sprawności umysłowej i funkcjonowania w różnych obszarach życia, również w życiu zawodowym ${ }^{31}$. Rezyliencja to pojęcie wywodzące się z psychologii i określające zespół cech wpływających

${ }^{28}$ R. Hanson, F. Hanson, Rezyliencja. Jak ukształtować fundament spokoju, sity i szczęścia, Sopot 2020, s. 10 .

29 Tamże.

30 E. Wędrychowska, 5 sposobów na to, jak budować swoją "warstwę ochronną", by radzić sobie w trudnych doświadczeniach zawodowych, http://ewedrychowska-coaching.pl/blog/rezyliencja5-sposobow-na-to-jak-budowac-swoja-warstwe-ochronna-by-radzic-sobie-w-trudnych-doswiadczeniach-zawodowych/) [dostęp:16.07.2020].

31 M. Gabrys, Rezyliencja, https://malgorzatagabrys.pl/rezyliencja/ [dostęp: 15.05.2020]. 
na to, jak człowiek radzi sobie w trudnych sytuacjach. Wśród nich wskazać można: poczucie autonomii, spokój w obliczu presji, racjonalne myślenie, poczucie własnej wartości, optymizm, szczęście oraz inteligencję emocjonalną, poczucie sensu i celu, poczucie humoru, altruizm, miłość i współczucie, charakter (integralność i siła moralna), ciekawość, równowagę, towarzyskość i kompetencje społeczne, a także zdolność adaptacji, umiejętność czerpania z doświadczeń oraz zdrowe nawyki, czyli optymalne radzenie sobie z różnymi sytuacjami życiowymi ${ }^{32}$. Umiejętność podejmowania decyzji, odpowiedzialność za swoje czyny, otwartość, umiejętność działania pod presją, to zdolności związane z rezyliencją, które są bardzo pożądane na rynku pracy, szczególnie w sytuacjach kryzysowych, mało stabilnych. Odporność psychiczna jest niezwykle ważną cechą osobowości, która według specjalistów badających rynek pracy przekłada się na skuteczność33. Wydaje się ona zatem szczególnie ważna w kontekście trudności, jakie pojawiły się na rynku pracy w czasie pandemii. Odporność psychiczna jest niezbędna do „właściwego” funkcjonowania na rynku pracy i tym samym staje się kolejnym niezbędnym elementem zatrudnialności. Tylko osoby radzące sobie w nowych trudnych sytuacjach, elastyczne, o odpowiednio wysokim poczuciu własnej wartości, odpowiedzialne, wyciągające wnioski będą atrakcyjne dla pracodawców.

Zatrudnialność jako ważna dyspozycja pracownika w XXI wieku, w moim odczuciu, w obliczu kryzysu zmienia swój kształt i bez wątpienia powinna zostać wzmocniona o kategorie związane z proaktywnością oraz rezyliencją. Dlatego, w perspektywie przyszłościowej zasadne wydaje się poszukiwanie takich rozwiązań, które będą ułatwiać rozwój pracowników, ale także wzmacniać ich kompetencje, nie tylko w obszarze stricte zawodowym, ale również w obszarze stanowiącym istotny element kompetencji zatrudnieniowych. Wzmocniona rezyliencją i postawami proaktywnymi zatrudnialność daje pracownikom szansę na efektywne funkcjonowanie na nowym, zmodyfikowanym, cyfrowym rynku pracy po pandemii nawet wtedy, kiedy świat wcześniej zaprojektowany będzie wymagał gruntownych zmian.

\section{Refleksje końcowe}

Współczesna sytuacja na rynku pracy, zarysowana w niniejszym opracowaniu, oraz próba identyfikacji kluczowych trendów bądź wyzwań pojawiających się w obszarze zatrudnienia pokazuje, iż lockdown był czasem pracy zdalnej, rosnącej automatyzacji, globalnej rewaloryzacji gospodarki opiekuńczej i bar-

${ }^{32}$ Tamże.

${ }^{33}$ Psychologgia-plus.pl, https://www.psychologgia-plus.pl/blog/rezyliencja-o-naszej-wewnetrznej-odpornosci/ [dostęp: 29:08.2020]. 
dziej widocznych mankamentów ochrony socjalnej w ramach rozwiniętych gospodarek, ale także czasem, który urzeczywistnił szanse rozwojowe organizacji, jak i samych pracowników, w innych zmodyfikowanych kierunkach. To także czas, który bardzo mocno zaznaczył potrzebę interwencji pomocowych, rozumianych jako wsparcie zewnętrzne i wewnętrzne w miejscu pracy, identyfikowaną zarówno wśród pracodawców, jak i pracowników. Wsparcie ukierunkowane na minimalizowanie strat związanych z lockdownem, ale też przygotowanie gospodarki i pracowników na czas po pandemii. Punktem wyjścia $\mathrm{w}$ projektowaniu tych interwencji staje się optyka postrzegania konsekwencji kryzysu spowodowanego wirusem. Rewizja dotychczasowego postrzegania świata pracy jest nieunikniona i tym ważniejsza, im większa jest determinacja wychodzenia z kryzysu. Zasadne zatem wydaje się poszukanie odpowiedzi na pytanie: czy na sytuację na rynku pracy, zmodyfikowaną przez koronawirusa, będziemy częściej patrzeć przez pryzmat szans czy zagrożeń? Oczywiście, sytuacja, jakiej doświadczył świat w 2020 roku jest bezprecedensowa i powinna uwrażliwić zarówno obywateli, ale także rządzących, polityków, naukowców, edukatorów na zagrożenia, których możemy doświadczyć w przyszłości. Jednak paradoksalnie kryzys może także stwarzać szanse na odbudowę obszarów dotychczas zaniedbanych oraz na umocnienie nowego podejścia w biznesie, które będzie skoncentrowane bardziej na pracowniku i jego podmiotowości, a nie wyłącznie na efektywności i produktywności firmy. Optyka, którą zastosujemy w dużym stopniu będzie zależała od ustalenia tego, co jest punktem dojścia, celem, który trzeba zrealizować oraz ustalenia, jakie kto, biorąc pod uwagę różnych aktorów funkcjonujących na rynku pracy, ma oczekiwania. Warto zauważyć, iż przed pandemią powszechne było przekonanie, że głównym wyzwaniem na drodze do osiągnięcia dobrobytu gospodarczego sprzyjającego włączeniu społecznemu jest tworzenie tak zwanych dobrych miejsc pracy. Niestety, długotrwałe skutki koronawirusa, z którymi będzie się mierzył świat przez najbliższe lata, przyczynią się do zmian strukturalnych, zmian zapotrzebowania na siłę roboczą oraz umiejętności w konkretnych zawodach i utrudnią osiąganie tego celu. Po raz kolejny, albo z większą siłą, zacznie przybywać prekariuszy i neetsów, a bezrobocie strukturalne będzie bardziej widoczne niż przed kryzysem. Jednak pomimo zagrożeń i trudności spowodowanych wirusem, pandemia otwiera także przestrzeń do dyskusji nad nowymi warunkami pracy, zarówno w obszarze organizacji, sposobu jej wykonywania i miejsca, uwzględniając nie tylko potrzeby firmy, ale przede wszystkim potrzeby pracowników, nie wykluczając ich indywidualnych preferencji. Kryzys pandemiczny obnażył w sposób bardziej rażący, niż kiedykolwiek wcześniej, niedoskonałości oraz nierówności w przestrzeni pracy. Jednocześnie urealnił potrzebę natychmiastowych, pilnych działań ukierunkowanych na ochronę miejsc pracy i utrzymanie „na powierzchni” zarówno dużych, jak i małych 
przedsiębiorców oraz zapewnienie wsparcia dochodów i innych sieci bezpieczeństwa bezpośrednio dla pracowników i gospodarstw domowych. Zdaniem S. Zahidi, należy uznać "ten moment za szansę na build back better (odbudowanie/zbudowanie od nowa) oraz położenie podwalin pod bardziej odporny rynek pracy oraz równiejszy świat" ${ }^{\prime 34}$. Autorka cytowanego opracowania wskazuje pięć sposobów zmierzających do osiągnięcia tego stanu:

- Double down on upskilling and reskilling - podwojenie/zwiększenie wysiłków ukierunkowanych na przekwalifikowanie oraz rozwijanie/ podnoszenie kompetencji;

- Identify the jobs of tomorrow - identyfikacja miejsc pracy przyszłości nowe proaktywne podejście do pracy jutra;

- Prioritize re-deployment and re-employment - nadanie priorytetu działaniom umożliwiającym przesunięcia pracownicze wewnątrz firmy i poza nią oraz działaniom ułatwiającym powrót na rynek pracy;

- Revalue essential work and improve the quality of jobs - rewizja dotychczasowych standardów pracy oraz podniesienie jakości pracy poprzez implementację nowych zasad związanych z ochroną socjalną pracowników;

- A collaborative recovery, reset and rebuild - odbudowa i poprawa współpracy pomiędzy podmiotami rynku pracy na poziomie krajowym i globalnym ${ }^{35}$.

Jak już wcześniej wspomniano, kryzys padnemiczny obnażył niedoskonałości i nierówności w różnych obszarach życia społecznego, także na rynku pracy, ale zmienił też sposób myślenia światowych przywódców na temat podstawowej wartości ludzkiego życia, ludzkiego potencjału i ludzkich środków do życia, co stało się ogromną szansą na zainwestowanie w najcenniejszy kapitał całego globu - kapitał ludzki ${ }^{36}$.

Epidemia przyszła $\mathrm{z}$ dnia na dzień, ale nie skończy się $\mathrm{w}$ ten sam sposób, a świat po pandemii nigdy nie będzie taki, jak przed nią, dlatego warto wykorzystać "czas pomiędzy” na przeprojektowanie priorytetów, ale także tworzenie warunków nowej, lepszej rzeczywistości zawodowej, w której będzie przestrzeń i czas dla „większej uważności na drugiego człowieka”, gdzie każdy pracownik będzie postrzegany w kategoriach wartości, a nie środków odpowiednich do realizacji konkretnych celów.

Sytuacja związana z wirusem pokazała wyraźnie, iż bardzo różnie reagujemy na nowe, nieoczekiwane sytuacje i to daje szansę na wykorzystanie różnorodności, również pokoleniowej. Przegrupowanie pracowników do no-

${ }^{34} \mathrm{~S}$. Zahidi, The future of work is here: 5 ways to reset labour markets after coronavirus recovery na: https://www.weforum.org/agenda/2020/05/the-future-of-work-is-here-5-ways-to-reset -labour-markets-after-coronavirus-recovery/ [dostęp: 30.05.2020].

35 Tamże.

${ }^{36}$ Tamże. 
wych zespołów, przydzielenie im nowych ról pomoże wzmocnić mobilność pracowniczą i być może utrwali odporność na kryzysowe sytuacje.

Wychodzenie z kryzysu zdaniem ekspertów będzie wymagać przesunięcia punktu ciężkości na nowe priorytety i nowe metody pracy, czyli nowe rozkłady godzin, pracę hybrydową, nowe zadania w ramach zespołów. Sposób, w jaki organizacje przygotują swoich pracowników do nowych, zrewidowanych warunków pracy oraz podejście do pracowników będą prawdopodobnie kluczowymi czynnikami warunkującym ich wydajność ${ }^{37}$. Ponadto, warto pamiętać, iż rynek pracy przyszłości nadal będzie potrzebował unikalnych ludzkich kompetencji typu myślenie systemowe czy wyobraźnia, innowacja i tym podobne, co jest dowodem na to, iż człowiek nadal jest istotnym zasobem na rynku pracy i nie wszystko podlega algorytmizacji. Wbrew pozorom robotom nadal trudno zrozumieć złożoność ludzkich emocji, będących mieszanką unikalnej genetyki i jednostkowych doświadczeń życiowych, a tym samym zapewnić osobiste, spersonalizowane doradztwo. Miejsca pracy, w których te umiejętności są bardzo potrzebne, nie są i prawdopodobnie szybko nie będą zagrożone, być może zostały nawet wzmocnione przez pandemię, która pokazała, iż relacje międzyludzkie, osobisty kontakt z drugim człowiekiem są nadal bardzo ważne.

Zatem, przyjmując optykę szans podczas analizy skutków COVID-19, warto zauważyć, iż kryzys sprowokował pogłębioną refleksję nad złożonymi relacjami pracownik-pracodawca, nad potrzebami obu stron tego układu, zmienił podejście do pracy wśród wielu pracowników, jak i podejście pracodawców do pracowników. Na rynku pracy przed COVID-em widoczne były cele, konkretne działania, środki do nich potrzebne, czasami bardziej te wyznaczane przez organizację, czasami przez pracownika. Bez względu na to, kto wyznaczał te cele, najczęściej były one podporządkowane jednej stronie, dominowały strategie typu wygrany - przegrany, w których pozycje zwycięzcy zmieniały się wraz z tendencjami na rynku pracy. COVID-19 pokazał, przynajmniej na chwilę, że jedynym słusznym rozwiązaniem jest realizacja celów, które zabezpieczą interesy obu stron. Niestety, nadal istnieje ryzyko, iż przedpandemiczne strategie, stosowane na rynku pracy, po raz kolejny zmienią się o 180 stopni i z rynku pracownika wrócimy automatycznie do rynku pracodawcy, a za jakiś czas odwrotnie. Należy jednak poczynić starania w kierunku poszukiwaniu nowych rozwiązań, które będą uwzględniały oczekiwania pracowników i pracodawców równocześnie.

Odzyskanie równowagi po pandemii wymaga nowych strategii personalnych, które uwzględnią zarówno działania krótkoterminowe związane z rozwiązywaniem bieżących problemów z wychodzeniem z kryzysu, ale też zmian bardziej perspektywicznych uwzględniających nowe podejście do pra-

${ }^{37}$ Tamże. 
cownika, integrującego cele organizacji z potencjałem pracowników, dające przestrzeń na zaangażowanie pracowników oraz odnalezienie ich tożsamości zawodowej. Nowe podejście do pracy, zmiana warunków jej organizacji i większe przyzwolenie na elastyczność oraz połączenie jej z bezpieczeństwem socjalnym pozwoli na wprowadzenie nowych procedur zarządzania talentami i nieliniowy rozwój kariery ${ }^{38}$.

Pandemia jest także szansą na rewizję dotychczasowych priorytetów, celów polityki personalnej wielu organizacji, jak i postaw samych pracowników wobec pracy, stała się motywatorem/akceleratorem do szukania nowych rozwiązań opartych na partnerstwie. Idea partnerstwa ożyła nie tylko w kontekście relacji personalnych wewnątrz organizacji, ale także w szerszym aspekcie. "Spłaszczenie” globalizacji podczas kwarantanny przyczyniło się do odrodzenia lokalności, a wraz z nią wybrzmiała potrzeba rozwijania partnerstwa społecznego w nowej, zaktualizowanej wersji ${ }^{39}$. Warto poszerzyć reprezentację partnerów, dostosować działania i budować nowe sojusze oparte na lokalności, które będą sprzyjały między innymi rozwiązywaniu problemów lokalnych rynków pracy.

Na koniec warto zauważyć, iż choć kształt rzeczywistości postpandemicznej jest bliżej nieokreślony, wpływ na jego kształt ma właściwie każdy obywatel. Pracownik, rozwijający swoje kompetencje przyszłości, wzmacniający swoją zatrudnialność, kształtujący proaktywne postawy wobec nieprzewidywalnej przyszłości oraz pracodawca, który będzie budował przyszłość swojej organizacji opierając się na zmodyfikowanych strategiach rozwoju, stawiających w centrum człowieka. Wreszcie, obok pracodawców, pracowników wskazać należy także grupy zawodowe, których działania będą szczególnie ważne, z punktu widzenia przyszłości rynku pracy. Profesjonaliści, pełniący role edukatorów, pedagogów, psychologów, doradców, których zadaniem jest nie tylko przeprowadzenie całego społeczeństwa przez czas pandemii, ale przede wszystkim przygotowanie go na nowe, jeszcze niezidentyfikowane zagrożenia bądź wyzwania.

\section{BIBLIOGRAFIA}

Bagiński K., Koronawirus a rynek pracy. Nie wszystkie branże stracity na epidemii, https:// www.money.pl/gospodarka/koronawirus-a-rynek-pracy-nie-wszystkie-branze-stracily-na-epidemii-sa-i-takie-ktore-szukaja-pracownikow-6494522090407553a.html [dostęp: 15.06.2020].

38 Tamże.

${ }^{39}$ Social dialogue for a changing world of work,. file:///C:/Users/Ania/Downloads/ CHAPTER\%206.pdf [dostęp: 12.09.2020]. 
Bańka A., Proaktywność a tryby samoregulacji. Podstawy teoretyczne, konstrukcja i analiza czynnikowa Skali Zachowań Proaktywnych w karierze, Stowarzyszenie Psychologia i Architektura, Poznań - Warszawa 2016.

Bergman Engineering, Rynek pracy w czasie koronawirusa - zamiast na umowe będa zatrudniać na kontrakt, https:// ksiegowosc.infor.pl/zus-kadry/zatrudnianie-i-zwalnianie/ 4573326,Rynek-pracy-w-czasie-koronawirusa-zamiast-na-umowe-beda-zatrudniac -na-kontrakt.html

Gabrys M., Rezyliencja, https://malgorzatagabrys.pl/rezyliencja/ [dostęp: 15.05.2020].

Goncalves A., Coronavirus: Fighting Unemployment by Learning Tech Skills, https:/ / youmatter.world/en/coronavirus-unemployment-tech-skills/. [dostęp: 18.07.2020].

Guziak J., TRENDY:Wielopokoleniowy zespót. Od milenialsów do pracowników z wieloletnim staże, na: https://www2.deloitte.com/pl/pl/pages/human-capital/articles/employee-experience/wielopokoleniowy-zespol.html?utm_campaign=Newsletter_HR\%40Transformation_10_2020_C-RG-CON-06787_pl_2020_Consulting_Email_pl\&utm_medium=email\&utm_source=Eloqua [dostęp: 20.08.2020].

Hanson R., Hanson F., Rezyliencja. Jak uksztattować fundament spokoju, sity i szczęścia, Gdańskie Wydawnictwo Psychologiczne, Sopot 2020.

Harrington B., Ladge J.J., Work-life integration: Present Dynamics and Future Directions for Organizations, Organizational Dynamics, 2009, vol. 38, no.2, https://gethppy.com/workplace-happiness/work-life-balance-to-work-life-blending, https://www.inc.com/ principal/forget-work-life-balance-work-life-blending-is-the-key-to-happiness.html, https:// www.rp.pl/Praca/190229534-Work-life-balance-i-work-life-integration--czym-charakteryzuja-sie-te-podejscia.html; https://www.hbrp.pl/b/work-life-integration/P9MVaF9Da [dostęp: 08.07.2020].

Hatalska N., Pracownik przyszłości, Infuture Institute, Gdańsk 2019.

Human Capital Trends 2019, Deloitte 2019.

Interia.pl, informacja prasowa, Pandemia zmusza wielu pracowników do zmiany zawodu, https:/ / biznes.interia.pl/praca/news-pandemia-zmusza-wielu-pracownikow-do -zmiany-zawodu,nId,4546953?parametr=zobacz_takze [dostęp: 17.06.2020].

Jarco M., Co ósma firma zwolniła pracowników, a 18 proc. Obniżłło lace, https:/ / www.codziennypoznan.pl/artykul/2020-05-05/badanie-co-osma-firma-zwolnila-pracownikow-a18-proc-obnizylo-place [dostęp: 31.05.2020].

Jeruszka U., Zatrudnialność w perspektywie pedagogiki pracy, Wydawnictwo Difin, Warszawa 2019.

Kabaj M., Wptyw systemów kształcenia zawodowego na zatrudnienie i bezrobocie młodzieży, Instytut Pracy i Spraw Socjalnych, Warszawa 2012.

Kwiatkowski S.M. (red.), Kompetencje przyszłości, Wydawnictwo FRSE, Warszawa 2018.

Michalska J., Patalan K., Przyszłość pracy post-Covid, https:/ / www.miesiecznik-benefit.pl/ wywiad/news/przyszlosc-pracy-post-covid-1/ [dostęp: 12.06.2020].

Newseria, Pandemia koronawirusa zmienia rynek pracy. W cenie będa zawody wykonywane zdalnie, https://www.codziennypoznan.pl/artykul/2020-05-13/pandemia-koronawirusa-zmienia-rynek-pracy-w-cenie-beda-zawody-wykonywane-zdalnie?fbclid= IwAR0AzirB8e5qZbIZZJpmg-B-1ghzg0gRZA3-ctjX813csLyVyy9BGER32mo [dostęp: 20.06.2020].

Portal pracuj.pl, https://porady.pracuj.pl/kariera-i-rozwoj/postawa-proaktywna-i-reaktywna-w-zyciu-zawodowym/ [dostęp: 15.07.2020].

Portal Rynekpracy.pl, Na pandemii koronawirusa najwięcej straca finansowo młodzi ludzie $i$ kobiety https://rynekpracy.pl/wiadomosci/na-pandemii-koronawirusa-finansowo -straca-najwiecej-mlodzi-ludzie-i-kobiety [dostęp: 29.09.2020]. 
Psychologgia-plus.pl, https://www.psychologgia-plus.pl/blog/rezyliencja-o-naszej-wewnetrznej-odpornosci/ [dostęp: 29:08.2020].

PulsHR.pl, https:/ / www.pulshr.pl/praca-tymczasowa/koronawirus-a-rynek-pracy-nadciaga-zmierzch-rynku-pracownika,72938.html

Pwc Polska, Młodzi Polacy na rynku pracy w nowej normalności, czerwiec 2020.

Schwartz J., Scoble-Williams N., Hatfield S., Volini E., COVID-19: Strategia zatrudnienia na czas wychodzenia z kryzysu wywołanego wirusem COVID-19, Deloitte 2020.

Social dialogue for a changing world of work, file:// C:/Users/Ania/Downloads/CHAPTER\%206.pdf [dostęp: 12.09.2020].

Szewczyk P., „Pokolenie Lockdown”, czyli nowe problemy młodych osób na rynku pracy, https:/ / www2.deloitte.com/pl/pl/pages/press-releases/articles/Pokolenie-Lockdown-czyli-nowe-problemy-mlodych-osob-na-rynku-pracy.html?nc=1\&utm_campaign=IP_pokolenie_lockdown_C-RG-CON-06447_pl_2020_General_Email_pl\&utm_medium=email\&utm_source=Eloqua [dostęp: 30.06.2020].

Szymański D., NBP kreśli czarny scenariusz dla rynku pracy w Polsce. „Coraz gorsze dopasowanie”, https://businessinsider.com.pl/finanse/makroekonomia/rynek-pracy-w-polsce -z-raportu-o-inflacji-narodowego-banku-polskiego/mk5dhhe) [dostęp: 18.07.2020].

Wędrychowska E., 5 sposobów na to, jak budować swoja "warstwe ochronna", by radzić sobie w trudnych doświadczeniach zawodowych, http://ewedrychowska-coaching.pl/blog/ rezyliencja-5-sposobow-na-to-jak-budowac-swoja-warstwe-ochronna-by-radzic-sobie -w-trudnych-doswiadczeniach-zawodowych/) [dostęp: 16.07.2020].

Włoch R., Śledziewska K., Kompetencje przyszłości. Jak je kształtować w elastycznym ekosystemie edukacyjnym?, DELab UW, Warszawa 2019.

Zahidi S., The future of work is here: 5 ways to reset labour markets after coronavirus recovery na: https://www.weforum.org/agenda/2020/05/the-future-of-work-is-here-5-ways-to -reset-labour-markets-after-coronavirus-recovery/ [dostęp: 30.05.2020]. 